\title{
Additional Freeze Drying Fig Fruit (Ficus carica $L$ ) Filtrate into Tris Egg Yolk Extender and Its Effect on Sperm Membrane Integrity and Acrosome of Kacang Buck
}

\author{
Lalu Ahmad Zaenuri ${ }^{1}$, Lukman², Oscar Yanuarianto ${ }^{3}$, I Wayan Lanus Sumadiasa and Rodiah ${ }^{4}$ \\ 1,2,4)Laboratory of Animal Reproduction and ${ }^{3)}$ Laboratory of Animal Nutrition Faculty of Animal Science, University of \\ Mataram JI. Majapahit No. 62 Mataram. Lombok, West Nusa Tenggara, Indonesia, 83125 \\ Corresponding author email: ahmadzaenuri@unram.ac.id
}

\begin{abstract}
A study was designed to determine Kacang buck sperm membrane integrity and acrosome reaction as to the effect of different concentration of freeze-drying fig fruit filtrate in tris egg yolk based extender. This study used 5 proven fertility Kacang goats aged 3-4 years, maintained by the Faculty of Animal Sciences, Mataram University, Indonesia. Semen was collected by artificial vagina at every five days. The collected semen was divided into four aliquots in accordance to the treatments extender such as Control (0 gr), T1 (0.02 $\mathrm{gr}), \mathrm{T} 2(0.04 \mathrm{gr})$ and T3 $(0.06 \mathrm{gr})$ freeze-drying fig fruit filtrate in tris egg yolk based extender $(\mathrm{gr} / \mathrm{v})$, respectively. Plasma membrane integrity and intact acrosome after re-concentration and preserved at $5 \circ \mathrm{C}$ were assessed visually at 0 and every 24 hours for 5 consecutive days. The statistical significance of the result was evaluated by a one way ANOVA for completely randomized design analysis of variance. Data were presented as Mean $\pm S D$. Results suggest that the mean percentages of sperm membrane integrity in T0, T1,T2 and $\mathrm{T} 3$ at $96 \mathrm{~h}$ post extended and preserve at $5 \circ \mathrm{C}$ were $34.3 \pm 5.3,40.6 \pm 4.7,44.8 \pm 5.4$ and $42.1 \pm 5,1$, respectively. The mean percentages of sperm acrosome intact were 16.4 $\pm 4.8,18.5 \pm 1.9,21.6 \pm 3.1$ and $19.6 \pm 2.8$, respectively. The results of the study suggested that additional $0.04 \mathrm{gr}$ freeze drying fig fruit filtrate into tris egg yolk based extender have a significant preservation effect on both spermatozoa membrane integrity and acrosome intact of kacang buck.

Key Words: Buck, Spermatozoa, Acrosome, membrane, fig fruit extract, freeze-drying
\end{abstract}

ABSTRAK. Penelitian bertujuan untuk mengetahui pengaruh suplementasi sari buah tin yang di freeze drying kedalam pengencer berbasis tris kuning telur terhadap keutuhan membran dan status akrosom spermatozoa kambing kacang yang disimpan pada suhu $5^{\circ} \mathrm{C}$. sampel semen diperoleh dari 1 ekor kambing kacang dewasa berumur 3 tahun. Koleksi semen dilakukan setiap 5 hari menggunakan vagina buatan. Semen yang terkumpul dibagi menjadi 4 bagian sesuai dengan perlakuan yaitu berturut-turut kontrol $(0 \mathrm{gr}), \mathrm{T} 1(0.02 \mathrm{gr}), \mathrm{T} 2(0.04 \mathrm{gr})$ and T3 ( $0.06 \mathrm{gr}$ ) freeze drying sari buah tin didalam pengecer berbasis tris kuning telur ( $\mathrm{gr} / \mathrm{v})$. Integritas plasma membran dan intak akrosom setelah pengenceran dan penyimpanan pada suhu $5^{\circ} \mathrm{C}$ diperiksa secara visual menggunakan mikroskop phase kontras pada 0 dan setiap 24 jam setelah pengenceran dan penyimpanan pada suhu $5^{\circ} \mathrm{C}$ selama 5 hari berturut-turut. Data dianalisis menggunakan one way ANOVA dan dipersentasikan dalam bentuk Mean \pm SE. Hasil penelitian menunjukkan bahwa, rataan persentase spermatozoa dengan plasma membran utuh pada pengencer T0, T1,T2 dan T3 pada 96 jam setelah pengenceran dan penyimpanan pada suhu $5^{\circ} \mathrm{C}$ berturut-turut $34.3 \pm 5.3,40.6 \pm 4.7,44.8 \pm 5.4$ dan $42.1 \pm 5,1$. Sedangkan rataan persentase spermatozoa dengan acrosom intak adalah $16.4 \pm 4.8,18.5 \pm 1.9,21.6 \pm 3.1$ dan 19.6 \pm 2.8 . hasil penelitian ini menyimpulkan bahwa, penambahan $0,04 \mathrm{gr}$ freeze drying sari buah tin kedalam pengencer berbasis tris kuning telur meningkatkan daya preservasinya terhadap keutuhan membran dan keutuhan akrosom spermatozoa kambing kacang.

Kata Kunci: kambing jantan, Spermatozoa, Acrosom, membran, ekstrak buah tin, kering beku

\section{Introduction}

Early capacitation of spermatozoa in vitro, followed by acrosome reaction results in rapidly energy loses and quickly dies (Zamfirescu et al. 2003). Integrity and functional activity of spermatozoa and acrosome play an important role in the process of fertilization. Therefore, the integrity of the membrane and acrosome is an indicator to estimate the spermatozoa fertility rate (Zamfirescu et al. 2003 and Hashida et al. 2005) and the necessities for the occurrence of attachment and the joining of spermatozoa with zona pellucida and acrosome reactions (Hashida et al. 2005).

Extenders were one of the most decisive factors to maintain the quality of both liquid and frozen semen. Many studies have been 
carried out to investigate the preservation effect extender containing organic materials. Papa et al. (2010), reported that substitution of egg yolk using soybeans lecithin tends to increase the preservation effect of extender in retaining mass motility, progressive motility and membrane integrity of the post-thawing frozen horse semen. Sumadiasa et al. (2015) reported that the substitution of $10 \%$ of $25 \%$ egg yolk using guava filtrate on CEP-2-based extender, had a very positive influence on the motility, viability, morphology and acrosomes of Bali cow spermatozoa. Bahmanpour et al. (2006) also reported that date fruit pollen also proved to improve the quality parameters of spermatozoa in mice.

Three previous studies (Zaenuri et al. 2013; Zaenuri et al. 2014a and Zaenuri et al. 2014b) carried out research to investigate the effect of fresh fig fruit ((Ficus carica $L$ and Ficus carica $R$ ) filtrate in tris egg yolk based extender in preserving buck semen quality. These studies noted that to some extent, additional fresh fig fruit filtrate in tris egg yolk based extender was able to maintain progressive motility, viability, sperm membrane integrity and acrosome of goat spermatozoa. However, preparation of freeze drying fig fruit filtrate is concurrently cheaper and prolonged, it expires quickly than fresh filtrate. This research was performed in order to know the preservation effect of freeze drying fig fruit filtrate in tris egg yolk based extender in maintaining the membrane integrity and acrosome of Kacang buck spermatozoa.

\section{Materials and Methods}

\section{Experimental Extender}

Preparation of fig fruit filtrate is carried out according to the method described by Zaenuri et al. (2014a). The fig fruit filtrate underwent freeze drying for $2 \times 24$ hours, then it was kept at room temperature. Preparation of standard extender was as described by Evans and
Maxwell (1989). The treatment extender comprising a standard extender (Evans and Maxwell 1989) was added to freeze-dried fig fruit extract $0 \mathrm{gr}$ (TO), $0.02 \mathrm{gr}$ (T1); $0.04 \mathrm{~g}$ (T2) and $0.06 \mathrm{gr}$ (T3) per $1000 \mathrm{ml}(\mathrm{v} / \mathrm{v})$ of extender, then homogenous using magnetic stirrer prior to use.

\section{Semen Collection, Evaluation and Extended}

This study used 5 proven fertility Kacang goats aged 3-4 years, maintained by Faculty of Animal Sciences, Mataram University, Indonesia. Semen was collected by artificial vagina at every five days. Initial evaluation for fresh semen was immediately performed in the laboratory including volume, colour, and consistency, followed by microscopic assessment including mass movement, wave motion (scale of 0-5), concentration and percentage of motile spermatozoa. The quality of each ejaculates to be suitable for a further process, were not less than $0.8 \mathrm{ml}$ in volume, more than $70 \%$ motile and 2.5 to $3 \times 10^{9} / \mathrm{ml}$ in concentration (Evans and Maxwell 1989).

The concentration of spermatozoa for each treatment was 75 million / $0.25 \mathrm{ml}$ treatment extender. Semen dilution was done by inserting the diluent gradually and shaking gently to homogeneous. Extended semen was incubated in water bath at $37^{\circ} \mathrm{C}$ for 30 minutes for antibiotics to function optimally. To prevent cold stress, the tube containing the semen was retained in the quilled water jacket so that the semen temperature will decrease from $30^{\circ} \mathrm{C}$ to 5으 within 1 hour (Hafez 2008).

\section{Plasma Membrane Integrity}

First of all, the prepared Hypo-osmotic solution was made with fructose $(8.72 \mathrm{~g} / \mathrm{l})$ and sodium citrate $(4.74 \mathrm{~g} / \mathrm{l})$ at $p \mathrm{H}$ of 8.05 (Susilawati, 2013). A volume of $10 \mu \mathrm{l}$ of semen was added to $1 \mathrm{ml}$ of the solution and incubated at $37^{\circ} \mathrm{C}$ for $40 \mathrm{~min}$. Immediately after the incubation, 1 drop of the semen was placed on a glass slide covered with a cover slide and evaluated under a phase-contrast microscope 
(CarlZeis, Germany) at 400 magnificent. Microscope fields were selected randomly. At least 200 spermatozoa were evaluated per slide and percentages of swollen tail spermatozoa were calculated. The percentage of spermatozoa with the intact membrane is the number of spermatozoa whose tail is circular, divided by 200 (Susilawati 2013; Ahmad et al. 2003).

\section{Intact Acrosome}

Acrosome intact was evaluated using the method as described by Tamuli and Watson (1994) as follows. First, the spermatozoa staining material comprises a stock tartrate phosphate buffer consisting of $50 \mathrm{mM}$ Disodium hydrogen anhydrous orthophosphate, $25 \mathrm{mM}$ Potassium dihydrogen orthophosphate, $77 \mathrm{mM}$ Potassium sodium tartrate. Secondly, these three ingredients were mixed together, stored in the refrigerator until the time of use. Thirdly, $50 \mathrm{mM}$ glucose with volume as needed was made. After that, it was continued by making stock Nigrosin Eosin consisting of $10 \mathrm{~g}$ of Nigrosin dissolved into $60 \mathrm{ml}$ of aquabides and boiled. After cooling, it was poured into a 100 $\mathrm{ml}$ reaction tube that already contains $0.7 \mathrm{~g}$ eosin using a glass filter paper. $7.5 \mathrm{ml}$ of $50 \mathrm{mM}$ glucose and $7.5 \mathrm{ml}$ Tartrate Phosphate Buffer $(\mathrm{TPB}=50 \mathrm{mM}$ Disodium hydrogen orthophosphate anhydrous, $25 \mathrm{mM}$ Potassium dihydrogen orthophosphate, $77 \mathrm{mM}$ Potassium sodium tartrate) was added. aquabides up to $100 \mathrm{ml}$ volume was added and then kept in the refrigerator. Fifthly, make Stock Giemsa by $0.7 \mathrm{~g}$ Giemsa added $75 \mathrm{ml}$ of absolute methanol and $25 \mathrm{ml}$ of glycerol and homogenized, store at 37 ㅇ C for 1 week, shake giemsa bottle daily. Stock giemsa will be ready after one week. Lastly, a stock fresh Giemsa Stain every day just prior to use was prepared. The fresh giemsa stain consists of $4.5 \mathrm{ml}$ of giemsa stock being mixed with $3 \mathrm{ml}$ of TPB $(50 \mathrm{mM}$ disodium hydrogen anhydrous orthophosphate, $25 \mathrm{mM}$ potassium dihydrogen orthophosphate, $77 \mathrm{mM}$ potassium sodium tartrate) and $32.5 \mathrm{ml}$ of aquabides. This solution was only made for single use, so the volume was made as needed.

To evaluate acrosome intact, mix a drop of semen and 3 drops of Nigrosin-Eosin in warm object glass and then leave for 30 seconds. Make a smear and dry on a warm plate. The smear that has been made was fixed on the TPB (TPB $=50 \mathrm{mM}$ disodium hydrogen anhydrous orthophosphate, $25 \mathrm{mM}$ potassium dihydrogen orthophosphate, $77 \mathrm{mM}$ potassium sodium tartrate) with $4 \%$ formaldehyde for $10 \mathrm{~min}$. After that, the smear was lifted and dried at room temperature then washed in tap water for 10-15 minutes, then rinsed with aquabides and left at room temperature a few minutes to dry. Next, soak the smears in fresh Giemsa Stain for $60 \mathrm{~min}$, dry it at room temperature. Wash the smears by putting it in a container of tap water for 10-15 minutes then rinsed with aquabides, lift the smears up and allow it for a few minutes at room temperature to dry. Calculate 200 spermatozoa for each treatment using a $1000 \mathrm{x}$ magnificent phase contrast microscope. This study only identifies intact acrosomes without distinguishing live and dead spermatozoa with intact or damaged acrosome.

\section{Statistical Analysis}

The statistical significance of the result was evaluated by a one way ANOVA completely randomized design analysis of variance using CoStat for windows statistical software (version 6.303). Data was presented as Mean \pm S.E. Probability $\mathrm{P}<0.05$ was considered significantly different.

\section{Results and Discussions}

\section{Plasma Membrane Integrity}

Percentages and standard deviation of spermatozoa membrane integrity are presented in Table 1. The percentages of spermatozoa membrane integrity of this study showed that since 72 hours the percentage of plasma spermatozoa membrane integrity in extender 
containing $0.04 \mathrm{gr}$ of fig fruit filtrate tended to be higher $(55.2 \pm 7.1)$ and there were statistically significant differences as compared to Spermatozoa plasma membrane integrity at $0.02 \mathrm{gr}$ and $0.06 \mathrm{gr}$ which are $40.6 \pm 4.7$ and $42.1 \pm 5.1$ except on control, respectively. The same trend occurred at 96 hours after being extended and stored. Membrane integrity and spermatozoa viability are the main requirements for fertilization (Mocé and Graham 2008).

The integrity of the goat spermatozoa plasma membrane integrity in extender containing $0.04 \mathrm{gr}$ of fig fruit filtrate is higher to that reported by some researcher. Anghel et al. (2010) found that, in addition to 0.1 and 1 $\mathrm{mM} \alpha$-tocopherol in Tris-based extenders, the percentage of plasma integrity of post-thawing goat spermatozoa membranes was

$52.72 \pm 2.08$ and $55.00 \pm 1.65$ compared to controls (49.75 \pm 2.6$)$. Ari and Daskin (2010) reported that the integrity of goat spermatozoa plasma membrane in Tris extender $+20 \%$ egg yolks was $38.0 \pm 3.4 \%$. Saraswat et al. (2012) reported that the addition of $1.5 ; 2.5$ and 3.5 $\mathrm{mM}$ of vitamin $\mathrm{E}$ in extenders and stored at $5 \circ \mathrm{C}$ which was examined after 96 hours, to obtain a percentage of plasma integrity of spermatozoa membranes $23.42 \pm 10.0 ; 24.07 \pm 10.09$ and 14.05 \pm 7.85 . Hu et al. (2009) reported that, addition of $1.25 ; 2.5 ; 3.75$ and $5 \mathrm{mg} / \mathrm{ml}$ of vitamin B12 in post thawing cattle semen obtained a percentage of plasma integrity of spermatozoa membrane consecutively $50.69 \pm 2.50 ; \quad 42.34 \pm 2.36 ; \quad 39.45 \pm 2.31$ and $37.46 \pm 1.76$.

Physiologically, the integrity of the spermatozoa membrane plays a vital role in the physiological processes of spermatozoa, including protecting and maintaining the motility of spermatozoa in the female reproductive tract, also the capacitation and fertilization so that the integrity of the membrane is one indicator that determines the fertility rate of spermatozoa (Mocé and Graham 2008 ; Zamfirescu et al. 2003).

Table 1: Percentage of Sperm Membrane Integrity in Tris Egg Yolk Based Extender Supplemented by Different Concentration of Freeze Drying Fig Fruit Filtrate at 5ㅇ.

\begin{tabular}{cccccc}
\hline $\begin{array}{c}\text { Freeze Drying } \\
\text { Fig Fruit Extract }\end{array}$ & \multicolumn{5}{c}{ Preservation (hours) } \\
\cline { 2 - 6 } (gr) & 0 & 24 & 48 & 72 & 96 \\
\hline 0 & $67.1 \pm 6.2$ & $63.7 \pm 4.2^{\mathrm{a}}{ }^{\mathrm{b}}$ & $57.8 \pm 9.6^{\mathrm{a}} \underline{\mathrm{a}}$ & $52.3 \pm 7.9^{\mathrm{a}}$ & $34.3 \pm 5.3^{\mathrm{c}}$ \\
0.02 & $68.8 \pm 6.4$ & $64.1 \pm 5.0^{\mathrm{a}} \mathrm{b}^{\mathrm{b}}$ & $56.1 \pm 5.5^{\mathrm{a}}$ & $50.3 \pm 5.6^{\mathrm{a}}$ & $40.6 \pm 4.7^{\mathrm{b}}$ \\
0.04 & $68.1 \pm 7.2$ & $61.4 \pm 6.1^{\mathrm{b}}$ & $57.9 \pm 9.9^{\mathrm{a}}$ & $55.2 \pm 7.1^{\mathrm{b}}$ & $44.8 \pm 5.4^{\mathrm{b}}$ \\
0.06 & $74.8 \pm 5.6$ & $69.3 \pm 5.3^{\mathrm{a}}$ & $54.0 \pm 9.1^{\mathrm{a}}$ & $51.5 \pm 5.2^{\mathrm{a}}$ & $42.1 \pm 5.1^{\mathrm{a}}$ \\
\hline
\end{tabular}

The values in the same column with different superscripts differ significantly $(\mathrm{P}<0.05)$

Table 2: Percentage of Sperm With Intact Acrosome in Tris Egg Yolk Based Extender Supplemented by Different Concentration of Freeze Drying Fig Fruit Filtrate at $5 \circ \mathrm{C}$.

\begin{tabular}{cccccc}
\hline $\begin{array}{c}\text { Freeze Drying Fig } \\
\text { Fruit Extract }\end{array}$ & \multicolumn{5}{c}{ Preservation (hours) } \\
\cline { 2 - 6 }$(\mathrm{gr})$ & 0 & 24 & 48 & 72 & 96 \\
\hline 0 & $40.6 \pm 4.9^{\mathrm{a}}$ & $36.2 \pm 4.4^{\mathrm{a}}$ & $21.8 \pm 5.4^{\mathrm{a}}$ & $19.5 \pm 4.4^{\mathrm{a}}$ & $16.4 \pm 4.8^{\mathrm{a}}$ \\
0.02 & $34.6 \pm 2.6^{\mathrm{a}} \mathrm{b}$ & $32.0 \pm 2.1^{\mathrm{b}}$ & $24.9 \pm 3.6^{\mathrm{b}}$ & $21.1 \pm 3.2^{\mathrm{ab}}$ & $18.5 \pm 1.9^{\mathrm{a}} \mathrm{b}$ \\
0.04 & $34.5 \pm 1.3^{\mathrm{b}}$ & $30.3 \pm 1.1^{\mathrm{b}}$ & $28.1 \pm 4.7^{\mathrm{b}}$ & $24.2 \pm 2.4^{\mathrm{b}}$ & $21.6 \pm 3.1^{\mathrm{b}}$ \\
0.06 & $32.7 \pm 3.1^{\mathrm{b}}$ & $30.9 \pm 3.1^{\mathrm{b}}$ & $26.4 \pm 2.5^{\mathrm{b}}$ & $22.6 \pm 2.8^{\mathrm{b}}$ & $19.6 \pm 2.8^{\mathrm{b}}$ \\
\hline
\end{tabular}

The values in the same column with different superscripts differ significantly $(P<0.05)$ 


\section{Intact Acrosome}

The percentage of mean and standard deviation of spermatozoa with intact acrosome is presented in Table 2. This study found that, the percentage of spermatozoa with intact acrosome in extender containing $0.04 \mathrm{gr}$ of fig fruit filtrate up to 96 hours post extended and stored at 5 으 was $21.6 \pm 3.1$ and was significantly $(P<0.05)$ higher than control extender (16.4 \pm 4.8$), 0.02 \mathrm{gr}(18.5 \pm 1.9)$ and 0.09 gr (19.6 \pm 2.8$)$ fig fruit filtrate, respectively. The results of this study are not much different from those reported by Saraswat et al. (2012) that, the percentage of intact acrosomes of Sirohi goat spermatozoa with extenders containing 2.5; 3.5; 5 and $7 \mathrm{mM}$ of vitamin $\mathrm{E}$ at 96 hours post extended and stored at 5 으 $\mathrm{C}$ were $22.1 \pm 3.1$; $28.5 \pm 4.2 ; 26.4 \pm 4.9$ and $24.4 \pm 3.1$. $\mathrm{Hu}$ et al. (2009) reported that, the addition of 1.25 ; 2.5 ; 3.75 and $5 \mathrm{mg} / \mathrm{mL}$ of vitamin B12 in cattle frozen semen post-thawing obtained the percentage of intact acrosomes were $67.25 \pm 2.74 ; \quad 60.61 \pm 2.85 ; \quad 54.06 \pm 2.27$ and $48.59 \pm 2.56$, respectively.

Acrosome has a greater influence than the spermatozoa motility rate on the result fertility rate (Sacke 1972). An important role of acrosome reactions is in the release of proteolytic enzymes that is necessary for sperm penetration via zonna pelucida in mammals (Talbot et al. 2003). Thus, an assessment of the integrity of the acrosome is necessary in order to determine the spermatozoa fertility rate, because spermatozoa with incomplete acrosome are negatively correlated with spermatozoa fertility (Garner and Hafez 2008). Therefore, preservation ability of extender should be the main concern so that the acrosome and fertility rate of spermatozoa could be preserved. Zaenuri et al. (2014) found that, the optimum concentration of fresh fig fruit filtrate in tris egg yolk based extender for optimum preservation ability is to preserve incapacitated intact acrosome and acceptable pregnancy rates that are found at fix time insemination of buck sperm when tris egg yolk based extender was supplemented with $6 \%$ fresh fig fruit filtrate (v/v).

Increased preservation of tris egg yolk based extender supplemented by fig fruit filtrate may be due to three main reasons. First, Fig fruit filtrate is not only a high concentration of exogenous antioxidants but also fructose and micro minerals, and it may be beneficial to the longevity of sperm quality preserved in tris egg yolk based extender (Zaenuri et al. 2014a). Secondly, every $100 \mathrm{gr}$ of fresh fig fruit contains $0.81,20.40,266.34,181.50$ and $0.46 \mathrm{mg} \alpha-$ tocopherol, total tocopherol, total phenol, vitamin $\mathrm{C}$ and $\beta$-carotene, respectively. Fig fruits are also rich in energy sources (g/100 g) such as protein (1.26), carbohydrate (24.27), glucose (17.58) and fructose (18.20) and finally, rich in minerals (mg/1000 g) including $\mathrm{Cu}(0.15)$, Mg (223.53) and Ca (0.044). Lastly, all of these microelements are indispensable for spermatozoa to neutralize the negative effects of free radicals from the residual metabolism of spermatozoa (Zaenuri et al. 2014b).

\section{Conclusions}

The addition of freeze-drying fig fruit extract at a definite concentration into the tris egg yolk based extender showed a positive impact on goat spermatozoa during preservation at 5 으. The concentration of fig fruit extract in the most optimized tris egg yolk based extender to preserve goat sperm plasma membrane integrity and acrosomes is $0.04 \mathrm{gr}$ in $100 \mathrm{ml}$ tris egg yolk based extenders.

\section{Acknowledgments}

Sincere appreciation addressed to Ministry of Research, Technology and Higher Education of the Republic of Indonesia who has financed this research through the Masterplan of Economic Development Acceleration and Expansion of Indonesia 2011-2025 (PENPRINAS MP3EI 2011-2025 budget year 2016-2019). 


\section{References}

Ahmad Z. M Anzar, M Shahab, N Ahmad and SMH Andrabi. 2003. Sephadex and sephadex ion exchange filtration I mproves the quality and free ability of low-grade buffalo semen ejaculates. Theriogenology 59: 1189-202.

Anghel A, S Zamfirescu, C Dragomir, D Nadolu, S Elena and B Florica. 2010. The effects of antioxidants on the cytological parameters of cryopreserved buck semen. Romanian Biotechnological Letters. 15: 3. Supplement.

Ari UG and A Daşkin. 2010. Freezing of Washed Angora Goat Semen with Extenders Added Bull or Ram Seminal Plasma. Kafkas Univ Vet Fak Derg 16 (2): 233-37.

Bahmanpour S, T Talaei, Z Vojdani, MR Panjehshahin, IA Poostpasand and $S$ Zareei. 2006. Ghaeminia Date palm pollen seems to cure male infertility by improving the quality of sperm parameters. However. further studies are needed to see its beneficial effects in man. Iranian Journal of Medical Sciences 31(4): 20812.

Evans ACO and Lonergan C P. 2010. Effect of storage duration. storage temperature. and diluents on the viability and fertility of fresh ram sperm. Theriogenology 73: 541-49.

Garner DL and ESE Hafez. 2008. Spermatozoa and seminal plasma. In: Reproduction in Farm Animal. Hafez. B. And Hafez. E.S.E. 7th edn, Lippincott Williams and Wilkins. Awollers Kluwer Company. Philadelphi. 96-109.

Hafez ESE. 2008. Preservation and Cryopreservation of gametes and Embryos. In: Reprodustion in Farm Animals. Hafez. E.S.E. 7th edn, Lippincott Williams and Wilkins. Awollers Kluwer Company. Philadelphia: 431-42.

Hashida NH, RB Abdullah, MH Rajikin and M Mat Noor. 2005. Ultrastructural studies of fresh, frozen-thawed and acrosome- reacted goat sperm. Biomedical Research 16 (2): 119-23.

Mocé E and JK Graham. 2008. In vitroevaluation of sperm quality. Animimal Reproduction Sciences 105: 104-118.

Papa FO, GB Felício, CM Melo, MA Alvarenga, B DeVita, BR Avanzi and JA Dell'Aqua Jr. 2010. Effect of substituting soybean lecithin for egg yolk in an extender used for the cryopreservation of stallion semen. Animal Reproduction Science 121S: S171-S72.

Saraswat S, R Priyadharsini, SK Jindal, S Yadav, N Ramachandran, SD Kharche and AK Goel. 2012. Effect of Antioxidants Supplementation at
RefrigerationTemperature on Sperm Motion Characteristics and Membran Integrity of Sirohi Buck Semen. Journal of Physiology Pharmmacy Advance. 2(1): 77-86.

Susilawati T. 2013. Spermatologi. Universitas Brawijaya Press. Malang, Indonesia.

Sumadiasa IWL, T Susilawati, G Ciptadi and N Isnaini. 2015. The potency of guava filtrate (Psidium guajava Linn) for preservation of Bali bull spermatozoa. Journal of Agriculture and Veterinary Science 8 (5): 51-57

Sacke RG. 1972. Semen quality tests and their relationship to fertility. NAAB procciding 4 th Technology conference on animal Reproduction and Insemination 22-28.

Slover HT. 1983. Determination of tocopherols and sterols by capillary gas chromatography. Journal of the American Oil Chemists Society 60: 152428.

Talbot P, Shur B D and Myles D G. 2003. Cell adhesion and fertilization: steps in oocyte transport, sperm-zona pellucida interactions and sperm-egg fusion. Biology of Reproduction 68:19.

Hu JH, QW Li, YL Chen, ZL Jiang , YH Jia, LQ Wang and BB Ou. 2009. Effects of addition of vitamin B12 to the extender on post-thaw motility. acrosome morphology. and plasma membran integrity in bull semen. Turkish Journal of Veterinary and Animal Sciences. 33(5): 379-84.

Zaenuri LA, T Susilawati, SB Sumitro and $S$ Wahyuningsih. 2013. The prospectus of local fig fruit (ficus glumerata Rob) extract to preserve goat sperm motility. Journal Kedokteran Hewan. 7(1): 26-28. (Article in Indonesian with an English Abstract).

Zaenuri LA, T Susilawati, SB Sumitro and S Wahyuningsih. 2014a. Effects of Additional Crude Extract of Fig Fruit (Ficus carica $L$ ) into Tris Egg Yolk Based Extender on Quality of Buck Semen. Journal of Biology, Agriculture and Healthcare 4 (9): 21-27.

Zaenuri LA, T Susilawati, SB Sumitro and S Wahyuningsih. 2014b. Preservation Effect of Crude Fig Fruit Filtrate (Ficus carica $L$ ) Added In to Tris Egg Yolk Based Extender on Capacitating. Acrosome and Fertility of Half Blood Boer Buck Spermatozoa. Journal of Agriculture and Veterinary Science 7 (5) Ver. II: 60-68.

Zamfirescu S, D Nadolu, V Ciupină and D Coprean. 2003. The biochemical and electronomicroscopic research of ram semen before and after freezing various extenders. National Congres of Biotechnology present and outlook in the third millennium. Bucharest-Roumania: 2 - 6. 